\title{
IMPLEMENTASI MODEL SIKLUS BELAJAR HIPOTETIKAL DEDUKTIF UNTUK MENINGKATKAN PENGUASAAN KONSEP DAN KETERAMPILAN BERPIKIR KREATIF SISWA SMA
}

\author{
Wahdatun Nisa Khoirunah' $^{1)}$, Suyatno ${ }^{2)}$, Muslimin Ibrahim ${ }^{3)}$ \\ ${ }^{1)}$ Program Studi Pendidikan Sains, Program Pascasarjana Universitas Negeri Surabaya \\ ${ }^{2),}{ }^{3)}$ Dosen Pascasarjana Prodi Pendidikan Sains Univesrtitas Negeri Surabaya \\ E-mail: chopedzzone_me@yahoo.co.id
}

\begin{abstract}
This study aimed to describe the feasibility, student activities, student response, student mastery of concepts, creative thinking skills, and the relationship between creative thinking skills with concept mastery, and obstacles after implementation of the Hypothetical Deductive learning cycle model on buffer solution topic. This study was conducted in three stages, namely preparation of teaching materials, validation and revision stages of teaching materials, and implementation the Hypothetical Deductive learning cycle model using the one group pretest-posttest design. Results of research showed that the feasibility of the lesson plan included in the excellent category, the dominant activity of students were to discuss with their group, students indicated a positive response to learning, the average gain score of concept mastery was 0.78 (high gain) and those of creative thinking skill was 0.62 (moderate gain), and there was a strong and significant correlation between creative thinking skill and student concept mastery with correlation value of 0.905 , and the main obstacles found at the first meeting was students difficulties in designing experiments and still not familiar with the learning model that applied. Based on the data analysis, it had been concluded that the hypothetical Deductive learning cycle model could increased students' creative thinking skills and student's concept mastery.
\end{abstract}

Keywords: Hypothetical Deductive Learning Cycle Model, Creative Thinking Skills, Concept Mastery

Abstrak: Penelitian ini ditujukan untuk mendeskripsikan keterlaksanaan, aktivitas siswa, respons siswa, penguasaan konsep siswa, keterampilan berpikir kreatif, hubungan antara keterampilan berpikir kreatif dengan penguasaan konsep siswa, dan hambatan-hambatan setelah implementasi model siklus belajar Hipotetikal Deduktif pada pokok bahasan larutan penyangga. Penelitian ini dilaksanakan dalam tiga tahap, yaitu tahap pembuatan perangkat pembelajaran, tahap validasi dan revisi perangkat pembelajaran, serta tahap implementasi model pembelajaran siklus belajar Hipotetikal Deduktif menggunakan rancangan One Group Pretest-Posttest Design. Hasil penelitian menunjukkan bahwa keterlaksanaan RPP termasuk dalam kategori sangat baik, aktivitas siswa yang dominan adalah berdiskusi dengan teman sekelompok, siswa menunjukkan respon positif terhadap pembelajaran, skor peningkatan penguasaan konsep siswa rata-rata sebesar 0,78 (gain tinggi) sedangkan skor peningkatan keterampilan berpikir kreatif rata-rata sebesar 0,62 (gain sedang), serta terdapat korelasi yang kuat dan signifikan antara keterampilan berpikir kreatif dan penguasaan konsep siswa, dengan harga koefisien korelasi sebesar 0,905, dan hambatan utama yang ditemukan pada pertemuan pertama yaitu siswa kesulitan dalam merancang eksperimen serta masih canggung dengan model pembelajaran yang diterapkan. Berdasarkan hasil analisis data dapat disimpulkan bahwa model siklus belajar Hipotetikal Deduktif dapat digunakan untuk meningkatkan keterampilan berpikir kreatif dan penguasaan konsep siswa.

Kata kunci: Model Siklus Belajar Hipotetikal Deduktif, Keterampilan Berpikir Kreatif, Penguasaan Konsep

\section{PENDAHULUAN}

Perkembangan teknologi dan informasi pada saat ini tidak lepas dari keterampilan berpikir kreatif manusia. Manusia yang dibekali akal, budi, dan karsa menciptakan perubahan-perubahan terhadap pengetahuan yang ada dan mengimplementasikannya untuk memecahkan masalah-masalah yang dihadapi. Upaya mendorong keterampilan berpikir kreatif digunakan sebagai bekal hidup untuk menghadapi tuntutan, perubahan, dan perkembangan zaman yaitu melalui pendidikan yang berkualitas, salah satunya diterapkannya Kurikulum 2013 yang lebih menekankan pada pendidikan berbasis karakter dan berbasis kompetensi. Diharapkan peningkatan tersebut dapat menghasilkan insan yang produktif, kreatif, inovatif, dan afektif melalui penguatan sikap, keterampilan, dan pengetahuan yang terintegrasi (Kemdikbud, 2012).

Pada kenyataannya, tujuan pendidikan belum tercapai secara maksimal. Hal itu terlihat pada hasil pencapaian Indonesia dalam TIMSS (Trends in Internationals and Science Study ) bidang sains yang cenderung menurun dari tahun 2007 ke 2011. Pada 
TIMSS tahun 2011, Persentase siswa Indonesia yang mencapai tingkat rendah, sedang, tinggi dan lanjut dalam bidang sains berturut-turut adalah 54\%, 19\%, 3\% dan $0 \%$. Dengan demikian, sekitar separuh peserta Indonesia tidak mencapai standar terendah TIMSS 2011, yaitu sekitar $46 \%$ untuk sains. Siswa belum bisa mencapai menggunakan pemahaman sains mereka dalam mendukung penyelesaian masalah untuk situasisituasi yang tidak familiar secara sains dan teknologi (Fleischman, et al., 2010).

Berdasarkan hasil angket yang disebar kepada 40 siswa kelas XI SMAN 1 Cerme Gresik pada penelitian pendahuluan, diperoleh data bahwa materi yang dianggap sulit untuk dipahami adalah Larutan Penyangga. Menurut mereka, hal ini dikarenakan materi ini bersifat abstrak, tidak terlalu dibahas hubungannya dengan kehidupan sehari-hari (kurang bermakna), identik dengan rumus-rumus dan soal-soal hitungan. Hal ini dibuktikan oleh banyaknya siswa yang tidak tuntas atau remidi. Berdasarkan tingkat penjenjangan berpikir kreatif oleh Siswono (2008), hasil analisis tes berpikir kreatif yang dilakukan, menunjukkan keterampilan berpikir kreatif para siswa pada kategori sangat kreatif $4 \%$, kreatif $16 \%$, cukup kreatif $33 \%$, dan tidak kreatif $47 \%$. Secara rinci pencapaian indikator berpikir kreatif siswa adalah fluency (kefasihan) 18\%, flexibility (keluwesan) 20\%, originality (kebaruan) $10 \%$, dan elaboration (elaborasi) $20 \%$.

Berdasarkan hasil observasi, pembelajaran kimia di SMAN 1 Cerme ditekankan pada pemahaman siswa tanpa melibatkan keterampilan berpikir kreatif melalui pencapaian indikator berpikir kreatif siswa. Guru sering tidak membiarkan siswa mengkonstruk pendapat atau pemahamannya sendiri terhadap konsep kimia. Dengan demikian, siswa tidak dapat mengembangkan keterampilan berpikir kreatif. Sementara itu, penguasaan konsep siswa akan meningkat secara signifikan setelah mereka dilatih dengan keterampilan berpikir tertentu (Langrehr, 2006). Oleh karena itu, pembelajaran kimia disekolah perlu dikembangkan melalui strategi-strategi pembelajaran yang secara langsung maupun tidak langsung dapat meningkatkan keterampilan berpikir kreatif (Siswono, 2008). Salah satu upaya tersebut yaitu dengan menerapkan pembelajaran model siklus belajar hipotetikal deduktif, model pembelajaran yang dilandasi pandangan konstruktivisme dari Piaget. Dalam siklus belajar hipotetikal deduktif, siswa belajar mulai dari pernyataan berupa pertanyaan kausal (sebab-akibat). Selanjutnya siswa diminta untuk merumuskan kemungkinan jawaban (hipotesis) atas pernyataan tersebut. Kemudian siswa diminta untuk menurunkan konsekuensikonsekuensi logis dari hipotesis dan merencanakan serta melakukan eksperimen (eksplorasi). Analisis hasil eksperimen menyebabkan beberapa hipotesis ditolak, sedang yang lainnya diterima (pengenalan konsep). Akhirnya konsep-konsep yang relevan dan pola-pola penalaran yang terlibat didiskusikan, dan diterapkan pada situasi yang lain dikemudian hari (aplikasi konsep). Keluaran akhir dari penerapan model pembelajaran siklus belajar hipotetikal deduktif akan terwujud bila proses dikelas melalui pembelajaran memberi kesempatan bagi siswa atau siswa mengembangkan potensinya untuk berpikir kreatif (Lawson, 1989).

Pada tahun 2007, Paul Williams mempublikasikan hasil penelitiannya bahwa memasukkan siklus belajar kedalam petunjuk mengajar terbukti menjadi metode yang efektif untuk merubah konsepsi fisik siswa pada pokok bahasan hukum Newton. Selain itu, penelitian yang dilakukan oleh Taufik (2009) menunjukkan bahwa siklus belajar hipotetikal deduktif secara signifikan lebih efektif untuk meningkatkan pemahaman konsep dan keterampilan generik sains siswa dibanding dengan pembelajaran tradisional. Qarareh (2012) juga menemukan adanya perbedaan yang signifikan pada pencapaian akademik kelas eksperimen yang belajar sains menggunakan model siklus belajar ini dibandingkan dengan kelas kontrol yang belajar menggunakan metode tradisional (berpusat pada guru).

Pada penelitian ini mencakup pengembangan perangkat pembelajaran dari Kompetensi Dasar materi yang dipilih yaitu menganalisis peran larutan penyangga dalam tubuh makhluk hidup serta merancang, melakukan, dan menyimpulkan serta menyajikan hasil percobaan untuk menentukan sifat larutan penyangga.

Perangkat pembelajaran yang baik adalah perangkat yang telah melalui tahap validasi ahli atau pakar dan direvisi. Sebelum perangkat divalidasi dan direvisi, perlu dilakukan perancangan pembelajaran yang menuntut keterlibatan siswa aktif dalam proses pembelajaran serta membimbing siswa menemukan sendiri produk dengan kemampuan tingkat lanjut tersebut, pada akhirnya diharapkan dapat memberdayakan keterampilan berpikir kreatif dan meningkatkan penguasaan konsep siswa.

Dari uraian di atas, peneliti tertarik mengadakan penelitian berjudul "Implementasi Model Siklus Belajar Hipotetikal Deduktif untuk Meningkatkan Penguasaan Konsep dan Keterampilan Berpikir Kreatif Siswa SMA"

\section{METODE PENELITIAN}

Penelitian ini terdiri dari dua jenis yakni penelitian pra eksperimen jenis One Group Pretest-Posttest Design dan penelitian korelasional yang didahului dengan pembuatan perangkat pembelajaran. Penelitian pra eksperimen digunakan untuk mengetahui pengaruh implementasi model Siklus Belajar Hipotetikal 
Deduktif terhadap penguasaan konsep dan keterampilan berpikir kreatif siswa. Sementara itu penelitian korelasional digunakan untuk mengetahui ada tidaknya hubungan yang signifikan antara keterampilan berpikir kreatif dengan penguasaan konsep siswa. Perangkat pembelajaran yang dibuat (Rencana Pelaksanaan Pembelajaran (RPP), Lembar Kegiatan Siswa (LKS), Handout, dan Lembar Tes Hasil Belajar (THB)) divalidasi oleh pakar terlebih dahulu sebelum diimplementasikan di lapangan. Pembuatan perangkat ini mengacu pada prosedur model 4D yang dikemukakan oleh Thiagarajan, et al. (1974) dan disesuaikan dengan kurikulum 2013 SMA.

Penelitian dilaksanakan di SMA Negeri 1 Cerme Gresik pada Semester Ganjil Tahun Pelajaran 2014/2015. Jumlah siswa yang dilibatkan dalam uji coba lapangan adalah sebanyak 28 orang. Pertimbangan yang mendasari pemilihan sekolah tersebut sebagai tempat penelitian yaitu keterbukaan sekolah terhadap upaya inovasi pendidikan, memiliki siswa yang berkemampuan heterogen serta minat belajar yang tinggi.

Instrumen yang digunakan dalam pengumpulan data terdiri dari lembar validasi perangkat pembelajaran, lembar pengamatan keterlaksanaan RPP, pengamatan aktivitas siswa, angket respon siswa, penilaian penguasaan konsep, dan penilaian keterampilan berpikir kreatif, dan pengamatan hambatan.

Data hasil validasi perangkat pembelajaran, pengamatan keterlaksanaan RPP, aktivitas siswa, angket respon siswa, penguasaan konsep, keterampilan berpikir kritis, dan hambatan dianalisis secara deskriptif. Besarnya peningkatan penguasaan konsep dan keterampilan berpikir kritis dianalisis dengan rumus Hake, 1999. Sementara itu korelasi antara keterampilan berpikir dan penguasaan konsep dianalisis secara inferensial melalui perhitungan koefisien KorelasiPearson menggunakan program SPSS.

\section{HASIL PENELITIAN DAN DISKUSI}

\section{A. Validitas Perangkat Pembelajaran yang}

Perangkat pembelajaran yang dibuat pada penelitian yakni RPP, handout, LKS, PPK, dan PKBK, dilakukan validasi oleh pakar sebelum diimplentasikan dalam pembelajaran. Dari hasil validasi RPP handout, LKS, PPK, dan PKBK diperoleh skor rata-rata masingmasing 4,49 dengan kategori sangat valid; 4,69 dengan kategori sangat valid; 4,67 dengan kategori sangat valid; 4,73 dengan kategori sangat valid, dan 4,63 dengan kategori sangat valid. Dengan demikian perangkat pembelajaran yang dibuat layak digunakan dalam pembelajaran.

\section{B. Keterlaksanaan RPP}

Pembelajaran kimia dengan menggunakan model siklus belajar Hipotetikal Deduktif dilaksanakan selama empat kali pertemuan. Topik yang dibahas pada pertemuan pertama sampai pertemuan keempat secara berurutan adalah (1) Pengertian dan sifat larutan penyangga, (2) Pembuatan larutan penyangga, (3) Perhitungan $\mathrm{pH}$ larutan penyangga, (4) Kegunaan larutan penyangga. Data keterlaksanaan RPP diperoleh dari hasil pengamatan pelaksanaan pembelajaran siklus belajar Hipotetikal Deduktif oleh dua orang pengamat. Hasil pengelolaan data keterlaksanaan pembelajaran secara ringkas dapat dilihat pada Tabel 1.

Tabel 1. Hasil Pengamatan Keterlaksanaan RPP

\begin{tabular}{|c|c|c|c|c|c|c|}
\hline \multirow[t]{2}{*}{ No } & \multirow{2}{*}{$\begin{array}{l}\text { Aspek yang } \\
\text { diamati }\end{array}$} & \multicolumn{4}{|c|}{ Penilaian RPP } & \multirow{2}{*}{$\begin{array}{l}\text { Rata } \\
\text {-rata } \\
\end{array}$} \\
\hline & & P1 & P 2 & P 3 & P4 & \\
\hline I & $\begin{array}{l}\text { Kegiatan } \\
\text { Pembelajaran }\end{array}$ & 4.79 & 4.75 & 4.78 & 4,89 & 4.80 \\
\hline II & $\begin{array}{l}\text { Pengelolaan } \\
\text { Kelas dan } \\
\text { Waktu }\end{array}$ & 4.83 & 4.92 & 4.75 & 5.00 & 4.88 \\
\hline & & & & & & 4.84 \\
\hline
\end{tabular}

Berdasarkan hasil penilaian pengamat diketahui bahwa skor rata-rata keterlaksanaan RPP sebesar 4,84 sehingga pembelajaran model siklus belajar Hipotetikal Deduktif termasuk dalam kategori terlaksana dengan sangat baik. Hal ini juga didukung oleh skor rata-rata reliabilitas instrumen keterlaksanaan pembelajaran adalah 95,04\%. Dengan demikian instrumen keterlaksanaan pembelajaran dengan model ini dalam kategori reliabel dan dapat digunakan untuk mengukur keterlaksanaan pembelajaran.

\section{Aktivitas Siswa}

Aktivitas siswa pada proses pembelajaran dengan model siklus belajar Hipotetikal Deduktif pada tiap pertemuan diamati oleh dua orang pengamat. Aktivitas siswa yang diamati tiap pertemuan ada 10 aktivitas, dan diperoleh nilai reliabilitas rata-rata 92,5 yang menunjukkan bahwa instrumen aktivitas siswa termasuk dalam kategori baik. Persentase aktivitas siswa tiap pertemuan dapat dilihat pada Gambar 1.

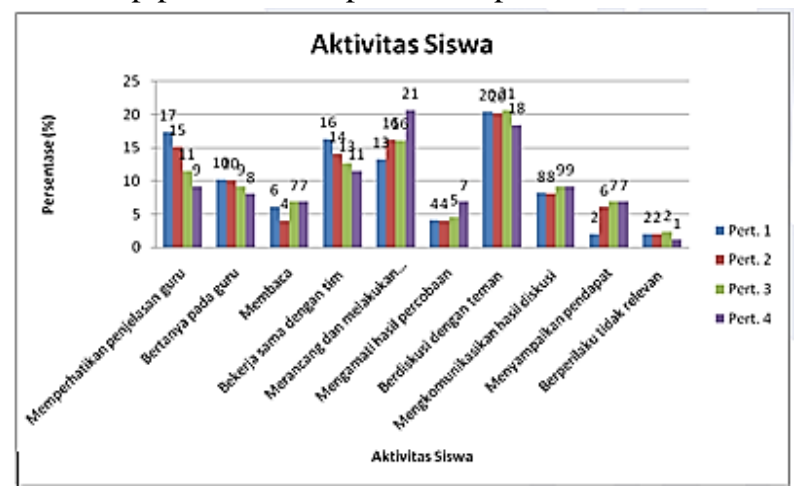

Gambar 1. Hasil Pengamatan Aktivitas Siswa 
Berdasarkan Gambar 1, terlihat aktivitas yang paling dominan adalah merancang dan melakukan percobaan. Hal ini menunjukkan bahwa pembelajaran model siklus belajar Hipotetikal Deduktif berpusat pada siswa.

\section{Respon Siswa}

Respon siswa terhadap kegiatan pembelajaran diperoleh dengan menggunakan instrumen angket. Instrumen ini berisikan respon terhadap materi pelajaran, lembar kerja siswa, cara guru mengajar, suasana belajar, minat mengikuti kegiatan belajar mengajar, hambatan-hambatan yang terjadi pada saat kegiatan belajar mengajar dan saran-saran selama mengikuti pembelajaran. Data persentase respon siswa yang diperoleh ditunjukkan pada Tabel 2.

Tabel 2. Hasil Perolehan Respon Siswa

\begin{tabular}{|c|c|c|c|c|c|}
\hline \multirow{3}{*}{ No. } & \multirow{3}{*}{ Uraian Pernyataan } & \multicolumn{4}{|c|}{ Penilaian/pendapat } \\
\hline & & \multicolumn{2}{|c|}{ Tertarik } & \multicolumn{2}{|c|}{ Tidak Tertarik } \\
\hline & & Frekuensi & $\%$ & Frekuensi & $\%$ \\
\hline \multirow[t]{7}{*}{1} & Pendapat siswa tentang: & & & & \\
\hline & a. Materi/isi pelajaran & 28 & 100 & 0 & 0 \\
\hline & $\begin{array}{l}\text { b. Lembar Kegiatan } \\
\text { Siswa (LKS) }\end{array}$ & 28 & 100 & 0 & 0 \\
\hline & c. Suasana belajar & 28 & 100 & 0 & 0 \\
\hline & d. Cara mengajar guru & 28 & 100 & 0 & 0 \\
\hline & & \multicolumn{2}{|c|}{ Mudah } & \multicolumn{2}{|l|}{ Sulit } \\
\hline & & Frekuensi & $\%$ & Frekuensi & $\%$ \\
\hline 2 & Pendapat siswa tentang: & & & & \\
\hline & a. Materi/isi pelajaran & 24 & 86 & 4 & 14 \\
\hline & $\begin{array}{l}\text { b. Lembar Kegiatan } \\
\text { Siswa (LKS) }\end{array}$ & 23 & 82 & 5 & 18 \\
\hline & c. Cara mengajar guru & 28 & 100 & 0 & 0 \\
\hline & & \multicolumn{2}{|c|}{ Berminat } & \multicolumn{2}{|c|}{ Tidak berminat } \\
\hline & & Frekuensi & $\%$ & Frekuensi & $\%$ \\
\hline 3 & $\begin{array}{l}\text { Minat siswa untuk } \\
\text { mengikuti kegiatan belajar } \\
\text { mengajar seperti yang telah } \\
\text { mereka ikuti saat ini pada } \\
\text { materi pokok lainnya. }\end{array}$ & 27 & 96 & 1 & 4 \\
\hline
\end{tabular}

Tabel 2 menunjukkan bahwa seluruh siswa tertarik terhadap materi pelajaran, lembar kerja siswa, cara guru mengajar, suasana belajar, hal ini ditunjukkan dengan nilai prosentase masing-masing $100 \%$. Siswa juga berminat mengikuti pembelajaran dengan menggunakan model siklus belajar Hipotetikal Deduktif (prosentase 96\%), Sebagian besar siswa merasa mudah dalam memahami materi pelajaran, lembar kerja siswa, dan cara guru mengajar, yang ditunjukkan dengan nilai prosentase masing-masing $86 \%, 82 \%$ dan $100 \%$.

\section{E. Penguasaan Konsep Siswa}

Penguasaan konsep siswa pada materi larutan penyangga diukur menggunakan PPK. PPK yang dikembangkan berupa tes obyektif pilihan ganda yang terdiri dari 20 butir soal. Aspek yang diukur dalam PPK dibatasi pada aspek kognitif produk dan proses. PPK diujikan sebelum pembelajaran (pretest) dan setelah pembelajaran (posttest). Skor yang diperoleh siswa dari PPK sebelum dan setelah pembelajaran secara visual disajikan pada Gambar 2.

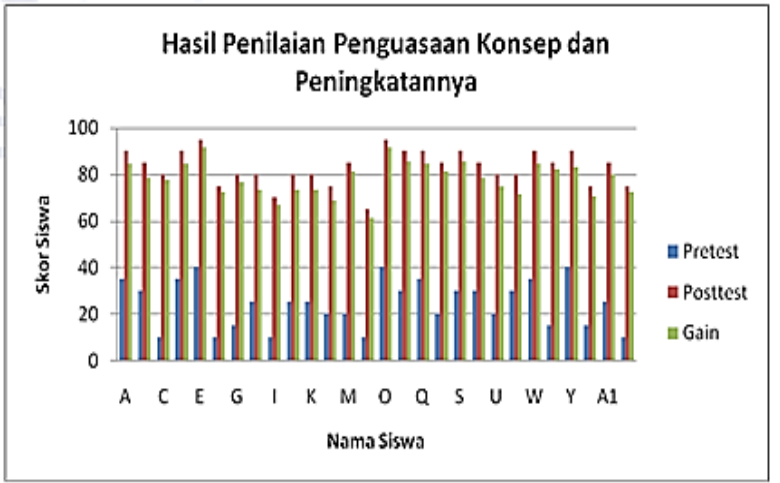

Gambar 2. Hasil Penilaian Penguasaan Konsep dan Peningkatannya

Berdasarkan Gambar 2 dapat dinyatakan bahwa tidak ada siswa yang tuntas pada saat pretest (ketuntasan $=0 \%)$ dan $93 \%$ siswa tuntas pada saat posttest. Data tersebut juga didukung oleh ketuntasan indikator pembelajaran yang mencapai $100 \%$. Dari hasil analisis peningkatan skor hasil PPK pada pretest (skor rata-rata $=24,50)$ dan posttest (skor rata-rata $=83,00$ ) diperoleh skor peningkatan (gain score) penguasaan konsep yang tinggi yakni $78 \%$. Ketuntasan yang tinggi dalam penguasaan konsep serta peningkatann skor penguasaan konsep yang tergolong tinggi menunjukkan bahwa model pembelajaran siklus belajar Hipotetikal Deduktif pada materi pokok larutan penyangga sangat efektif dalam meningkatkan penguasaan konsep siswa. Hal ini sesuai dengan teori Piaget yang menyatakan bahwa pengetahuan diperoleh dari tindakan (Slavin, 2006). Keterlibatan aktif siswa dalam mengkonstruksi pengetahuan, terutama pada bagian eksplorasi, pengenalan konsep, dan penerapan konsep dalam model ini, telah membantu terjadinya proses asimilasi dan akomodasi materi larutan penyangga dalam struktur kognitif mereka.

Hal ini didukung dengan data hasil pengamatan aktivitas siswa seperti merancang dan melakukan percobaan, bekerja sama dengan tim sekelompok, dan mengkomunikasikan hasil diskusi di depan kelas. Tingginya Interaksi sosial dalam kelompok maupun antar kelompok dalam pembelajaran siklus belajar Hipotetikal Deduktif, menurut Vygotsky (Slavin, 2009) dapat memperbesar tingkat perkembangan potensial siswa sehingga zona perkembangan terdekatnya meningkat. Keterlibatan siswa secara aktif dalam pembelajaran berbasis inkuiri dapat meningkatkan penyimpanan informasi dalam memori jangka panjang sehingga memperbesar penguasaan konsepnya (Gagne, 1982 dalam Slavin, 2009). Penguasaan konsep yang tinggi juga disebabkan oleh fase-fase dalam siklus belajar Hipotetikal Deduktif mampu mendorong siswa berpikir dan bekerja atas inisiatif sendiri sehingga menimbulkan motivasi baik intriksik maupun ekstrinsik. Timbulnya motivasi akan menyebabkan 
meningkatnya gairah atau semangat serta kesadaran belajar siswa pada akhirnya dapat meningkatkan penguasaan konsep.

\section{F. Keterampilan Berpikir Kreatif}

Keterampilan berpikir kritis siswa diukur menggunakan PKBK. Tes tersebut terdiri dari 5 butir soal berbentuk uraian (essay). Indikator keterampilan berpikir kreatif yang diukur adalah (1) fluency (kelancancaran), (2) flexibility (keluwesan), (3) elaboration (kerincian), dan (4) originality (keaslian) (Williams dalam Munandar, 1999). Seperti halnya PPK, PKBK juga diberikan sebelum pembelajaran (pretest) dan setelah pembelajaran (posttest). Skor hasil PKBK sebelum dan setelah pembelajaran disajikan secara visual pada Gambar 3.

Dari hasil analisis skor PKBK diketahui bahwa skor rata-rata pretest dan posttest masing-masing sebesar 28,21 dan 71,71. Dengan demikian skor peningkatan (gain score) yang diperoleh sebesar $62 \%$ dengan kategori sedang.

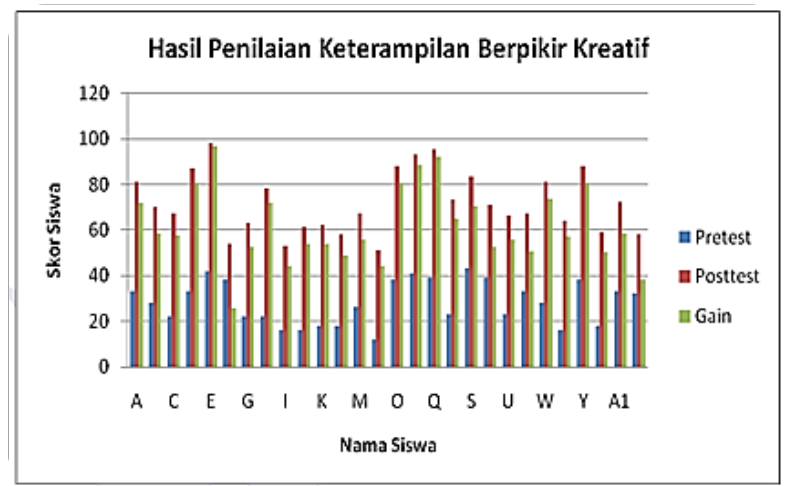

Gambar 3. Hasil Penilaian Keterampilan Berpikir Kreatif dan Peningkatannya

Tingginya skor rata-rata hasil PKBK serta skor pencapaian keterampilan berpikir kreatif siswa menunjukkan bahwa model pembelajaran siklus belajar Hipotetikal Deduktif dipadu dengan perangkat yang dikembangkan dapat digunakan merangsang keterampilan berpikir kreatif siswa. Aktivitas siswa dalam menggali keempat aspek berpikir kreatif melalui perancangan penyelidikan, di mana siswa diberi kesempatan untuk menuangkan, mempertimbangkan, mendiskusikan serta merinci ide-ide ke dalam langkahlangkah penyelidikan (fase eksplorasi), mengkomunikasikan hasil penyelidikannya yang juga melibatkan keempat aspek berpikir kreatif (fase pengenalan konsep), menerapkan ilmu pengetahuan yang diperolehnya melalui eksplorasi dan pengenalan konsep (fase penerapan konsep) keempat aspek berpikir kreatif tersebut kembali diperlukan dalam menyelesaikan permasalahan yang disajikan. Semakin banyak ide-ide baru yang dimunculkan oleh siswa dalam menyelesaikan pemecahan masalah maka akan meningkatkan berpikir kreatif siswa. Fase-fase dalam pembelajaran Siklus Belajar Hipotetikal Deduktif didukung oleh Vygotsky (John-Steiner \& Mahn, 1996; Karpov \& Bransford, 1995 dalam Slavin, 2006: 243), menekankan metode pengajaran di kelas pada pembelajaran sosial (kooperatif), bahwa interaksi sosial dengan orang dewasa dan teman sebaya yang lebih mampu membantu terbentuknya ide baru dan memperkaya perkembangan intelektual siswa, sehingga berpengaruh pada peningkatan berpikir kreatif siswa.

Hasil penelitian ini didukung oleh penelitian sebelumnya yang dilakukan oleh Taufiq (2009) yang menunjukkan bahwa hasil penerapan model siklus belajar hipotetikal deduktif secara signifikan lebih efektif dalam meningkatkan pemahaman konsep siswa dan keterampilan generik sains. Hasil penelitian Akar, Elvan (2005) yang menyimpulkan bahwa model siklus belajar mampu meningkatkan hasil belajar, Keterampilan berpikir kreatif, aktivitas pembelajaran, dan motivasi siswa dalam belajar sains, juga sangat mendukung hasil penelitian ini.

Tingginya skor peningkatan penguasaan konsep dan keterampilan berpikir kritis siswa didukung oleh data aktivitas siswa. Aktivitas siswa dalam pembelajaran dengan model siklus belajar Hipotetikal Deduktif lebih dominan dibandingkan dengan aktivitas guru (Gambar 1). Dengan demikian pembelajaran berpusat pada siswa (student centered learning) dapat diwujudkan. Dukungan lainnya berasal dari data angket respon siswa yang disajikan pada Tabel 2. Data tersebut menunjukkan bahwa $96 \%$ siswa berminat dan termotivasi mengikuti pembelajaran yang menerapkan model siklus belajar Hipotetikal Deduktif pada materi pokok larutan penyangga.

\section{G. Hubungan Antara Keterampilan Berpikir Kritis dan Penguasaan Konsep}

Dalam penelitian ini terdapat sebuah hipotesis yang akan diuji kebenarannya yakni "Ada hubungan signifikan antara keterampilan berpikir kreatif dengan penguasaan konsep siswa setelah implementasi model siklus belajar Hipotetikal Deduktif'. Sebelum dilakukan uji hipotesis penelitian, terlebih dahulu dilakukan uji normalitas populasi. Dalam penelitian ini yang dijadikan populasi adalah skor hasil PPK dan PKBK. Hasil uji normalitas menggunakan program SPSS menunjukkan bahwa data skor hasil tes penguasaan konsep dan tes berpikir kreatif berdistribusi normal karena nilai signifikansi Kolmogorov-Smirnov dan signifikansi Shapiro-Wilk lebih besar dari 0,05 (Fraenkel, 2009).

Selanjutnya berdasarkan hasil perhitungan koefisien korelasi Pearson antara keterampilan berpikir kreatif (variabel $\mathrm{X}$ ) dengan penguasaan konsep siswa (variabel Y) menggunakan program SPSS, diperoleh 
harga koefisien korelasi (r) sebesar 0,905 dan nilai signifikansi sebesar 0,000 . Karena nilai signifikansi lebih kecil dari 0,05 maka harga koefisien korelasi yang diperoleh bersifat signifikan. Dengan demikian hipotesis yang berbunyi "Ada hubungan yang signifikan antara keterampilan berpikir kreatif dengan penguasaan konsep siswa setelah implementasi model siklus belajar Hipotetikal Deduktif" dapat diterima. Diterimanya hipotesis tersebut dapat diterjemahkan bahwa semakin tinggi keterampilan berpikir kreatif siswa, maka semakin tinggi pula tingkat penguasaan konsepnya. Hal ini sesuai dengan pemikiran Langrehr (2006) bahwa penguasaan konsep siswa akan meningkat secara signifikan setelah mereka dilatih dengan keterampilan berpikir tertentu.

\section{H. Hambatan-hambatan}

Pada pertemuan pertama siswa kesulitan dalam merancang eksperimen karena pada pertemuanpertemuan sebelumnya siswa belum pernah merancang eksperimen namun langsung melakukan eksperimen sesuai dengan prosedur yang ada di LKS. Siswa juga masih canggung dengan model pembelajaran yang diterapkan sehingga siswa butuh waktu lama untuk mengerti apa yang harus dilakukan dan guru agak kesulitan dalam mengalokasikan waktu.

\section{KESIMPULAN}

\section{A. Simpulan}

Berdasarkan hasil analisis data dan diskusi hasil penelitian pada uji coba lapangan, maka dapat disimpulkan bahwa implementasi pembelajaran kimia menggunakan model siklus belajar Hipotetikal Deduktif pada materi pokok larutan penyangga dapat meningkatkan penguasaan konsep dan keterampilan berpikir kreatif siswa. Terdapat hubungan positif yang signifikan antara penguasaan konsep dengan keterampilan berpikir kreatif siswa setelah implementasi model ini.

\section{B. Saran}

Berdasarkan hasil penelitian yang telah dilakukan, disarankan bahwa hendaknya sebagai guru pengelola kelas untuk perlu lebih memperhatikan pengelolaan waktu dan pembimbingan siswa agar pembelajaran terlaksana dengan baik.

\section{REFERENSI}

Akar, E. (2005). "Effectiveness of 5E Learning Cycle Model on Students' Understanding of AcidBasemConcept". Diunduh dari http:www.ifets.info/journals/12_4/29.pdf pada tanggal 8 Juli 2012.

Fleischman, H.L., Hopstock, P.J., Pelczar, M.P., et al. (2010). Highlight From PISA 2009: Performance of U.S. 15-Years-Old Students in Reading, Mathematics, and Science Literacy in an International Context. NSES: U.S. Department of Education.

Fraenkel, J.R. and Wallen, N.E. (2009). How to Design Evaluate Research in Education. Seventh Edition. New York: McGraw-Hill, Inc.

Hake, R.R. (1999). "Analyzing Change/Gain Score". AERA-D-American Educational Research Association's Division. Measurement and Research Methodology. Tersedia di http://www.physics.indiana.edu/ sdi/AnalyzingC hange-Gain.pdf.

Langrehr, J. 2006. Thinking Skills, Edisi Pertama. Jakarta: PT.Gramedia

Lawson, A.E., Abraham, M.R., and Renner, J.W. (1989). "A Theory of Instruction: Using The Learning Cycle to Teach Science Concepts and Thinking Skills". Narst Monograph, Number One.U.S. Department of Education.

Martin, M.O., Mullis, I.V.S., Foy P., and Stanco, G.M. (2012). TIMSS 2011 International Results Science. USA: TIMSS \& PIRLS International Study Center, Lynch School of Education, Boston College.

Mulyasa, H.E.(2013). Pengembangan dan Implementasi Kurikulum 2013. Bandung: PT Remaja Rosdakarya.

Munandar, U. (1999). Kreativitas \& KeberbakatanStrategi Mewujudkan Potensi Kreatif dan Bakat. Jakarta: PT Gramedia Pustaka Utama.

Munandar, U. (2009). Pengembangan Kreativitas Anak Berbakat. Jakarta: Rineka Cipta.

Peraturan Menteri Pendidikan dan Kebudayaan Nomor 54 Tahun (2013). Standar Kompetensi Lulusan Pendidikan Dasar dan Menengah. Jakarta: Depdikbud.

Peraturan Menteri Pendidikan Dan Kebudayaan Republik Indonesia Nomor Tahun (2013). Silabus Sekolah Menengah Atas/Madrasah Aliyah. Jakarta: Depdikbud.

Priyatno, Duwi. (2013). Mandiri Belajar Analisis Data dengan SPSS. Yogyakarta: Mediakon.

Qarareh, A.O. (2012). "The Effect of Using the Learning Cycle Method in Teaching Science on the Educational Achievement of the Sixth Graders". International Journal of Educational Science, Vol. 4 No. 2, pp. 123-132.

Siswono, Tatag. Y.E. (2008). Model Pembelajaran Matematika Berbasis Pengajuan dan Pemecahan Masalah untuk Meningkatkan Kemampuan Berpikir Kreatif. Surabaya: Unesa University Press.

Slavin, R.E. (2006). Educational Psychology: Theory and Practice. Sixth Edition. New York: Allyn 


$$
\text { and Bacon. }
$$

Sudjana. (1986). Metode Statistika. Bandung: Tarsito. Sugiyono. (2007). Metode Penelitian Kuantitatif, Kualitatif, dan $R \& D$. Cetakan Ketiga. Bandung: Penerbit Alfabeta.

Taufik, Wiyono, K. (2012). The Application of Hypothetical Deduktive Learning Cycle Model To Improve Senior High School Students' Science Generic Skills On Rigid Body Equilibrium. (Proceeding The Third International Seminar On Science Education).

Thiagarajan, S., Semmel, D.S., Semmel, M.I. (1974).
Instruction Development For Training Teachers Of Exceptional Children. Indiana: Indiana Unirvercity.

Watkins, Marley W. and Pacheco, Miriam. (2000). Interobserver Agreement in Behavioral Research: Importance and Calculation. Journal of Behavioral Education, Vol. 10, No. 4, pp. 205-212.

Yamamoto, K. (1964). “A Further Analysis of The Role of Creative Thinking in High School Achievement". The Journal of Psicology, Vol. 58, pp. 277-283. 